\title{
SUOMALAISEN LEIVÄN FYTIINIHAPPOPITOISUUDESTA
}

\author{
Rakel Kurkela, Eeva Korhonen, Marjatta Rossander ja \\ PaAvo RoINE
}

Yliopiston ravintokemian laitos, Helsinki.

Saapunut 20.4. 1953

Viljatuotteiden rakitogeenisen vaikutuksen totesi ensimmäisenä MELLANBy (11) osoittamalla, että nuoret koiranpennut sairastuivat sitä vaikeampaan riisitautiin, mitä enemmän niiden ruoka sisälsi viljatuotteita. BRUCE ja CALLOw (3) liittivät rakitogeenisen vaikutuksen viljatuotteiden korkeaan fytiinihappopitoisuuteen. Koska suurin osa jyvien sisältämästä fosforista on fytiinihapon Ca- ja Mg-suolana, joka ei sellaisenaan imeydy, ja hajoaa ihmisen ruoansulatuskanavassa hyvin vähäisessä määrässä inositoliksi ja fosforihapoksi (18), päättelivät BRUcE ja CALLow viljan aiheuttaman riisitaudin johtuvan imeytyvän fosforin puutteesta. HARRISON ja Mellanby (5) puolestaan esittivät kokeittensa perusteella viljatuotteiden aiheuttaman riisitaudin synnystä toisen teorian. Sen mukaan kalsiumfytaatin liukenevaisuus on niin huono, että se saostuu suolistossa vallitsevissa olosuhteissa. Seurauksena on, että tämä kalsiummäärä ei imeydy, ja riisitauti aiheutuu siis kalsiumin puutteesta. Hoff-Jörgensen (6) totesikin, että fytiinihappo muodostaa pH 4.6 ja 6.9:n välillä liukenemattoman pentakalsiumfytaatin, jonka muodostumisesta suolistossa fytiinihapon kalsiumin absorptiota häiritsevä vaikutus näyttää johtuvan.

Verrattaessa toisiinsa eri viljalajien rakitogeenista vaikutusta ja fytiinihappopitoisuutta havaittiin, etteivät nämä olleetkaan aina suoraan verrannollisia kuten Mellanbyn teorian mukaan olisi ollut odotettavissa. Niinpä esim. kauran ja maissin vaikutus oli suurempi kuin niiden fytiinihappopitoisuus olisi edellyttänyt (4). Tämä ristiriita sai selityksensä PEdersenin (14) selvitettyä, että eri viljalajien rakitogeeninen vaikutus oli riippuvainen paitsi niiden fytiinihappopitoisuudesta myös niiden sisältämän fytiinihappoa hajoittavan entsyymin, fytaasin, aktiivisuudesta. Pedersen totesi, että voimakkaimmin rakitogeenisiksi havaituissa viljalajeissa kaurassa ja maississa fytaasin aktiivisuus oli hyvin pieni verrattuna esim. vehnään ja rukiiseen. On ilmeistä, että viljan sisältäessä aktiivista fytaasia tämä entsyymi hajoittaa osan fytiinihaposta ruoan valmistuksen aikana. Tämä fytiinihapon entsymaattinen hajoaminen on merkittävä etenkin leivän valmistuksessa, 
jossa entsyymillä on mahdollisuus toimia suhteellisen kauan. Leivän fytiinihappopitoisuus onkin, kuten monissa maissa suoritetuissa tutkimuksissa on osoitettu $(7,9,16,17,13,20)$, huomattavasti alhaisempi kuin vastaavien jauhojen, määrän riippuessa käytetyn viljatuotteen laadusta ja leivän valmistustavasta. Valkean vehnäleivän fytiinihappopitoisuus on eri tutkimusten mukaan hyvin alhainen $(0-28$ $\mathrm{mg} / 100 \mathrm{~g})(7,17)$, kokojyvävehnäleivän taas huomattavan korkea $(120-320$ $\mathrm{mg} / 100 \mathrm{~g})$ (17). Fytiinihapon hajoamiselle erityisen edulliseksi on todettu ruisleivän valmistus hapattamalla, jolloin jauhojen fytiinihapon on parhaassa tapauksessa todettu hajonneen kokonaan (17).

Suomalaisessa ruokavaliossa on viljatuotteita suhteellisen runsaasti ja ne nautitaan valtaosalta leipänä ja puuroina. Puuroja valmistettaessa lisätään viljatuote yleensä kuumaan veteen, joten tällöin ei entsymaattista fytiinihapon hajoamista sanottavasti ennätä tapahtua. Puurojen fytiinihappopitoisuus onkin täten helposti arvioitavissa kun käytetyn viljatuotteen fytiinihappopitoisuus tunnetaan. Leipien suhteen asia on olennaisesti toinen, koska fytiinihappopitoisuuteen vaikuttavat tällöin muutkin tekijät. Jotta voitaisiin saada yleiskuva leipienkin fytiinihappopitoisuudesta ja siten koko fytiinihappokysymyksen merkityksestä suomalaisessa kansanravitsemuksessa, esitetään seuraavassa tuloksia tutkimuksista, joissa määritettiin tärkeimpien suomalaisten leipätyyppien fytiinihappopitoisuuksia.

\section{Tutkittu aineisto ja käytetyt menetelmät}

Tutkimuksen kohteena olivat seuraavat leipätyypit: pehmeä ja kova ruisleipä (hapan ja happamaton), grahamleipä, ohraleipä, ohravehnäleipä ja valkea vehnäleipä (ranskanleipä). Leivät saatiin pääasiassa Osuusliike Elannon, Helsingin Meijeriliike Oy:n ja Helsingin Höyryleipomon leipomoista ${ }^{1}$ ja joitakin valmistettiin laboratoriossa itse. Muutamia happamia ruisleipiä hankittiin lisäksi maaseudulta. Leivistä määritettiin kuiva-aine, $\mathrm{pH}$, ja fytiinihappofosfori sekä leipien valmistukseen käytetyistä jauhoista kuiva-aine, fytiinihappofosfori ja kokonaisfosfori.

Kuiva-aineen määrityksessä leipä leikattiin n. $0.5 \mathrm{~cm}: n$ paksuisiksi viipaleiksi, jotka esikuivattiin korkeintaan $50^{\circ} \mathrm{C}: n$ lämpötilassa. Sen jälkeen leipä jauhettiin ja punnitut näytteet kuivattiin $1 \mathrm{t} 130 \pm 3^{\circ} \mathrm{C}$ :ssa.

Jauhojen kuiva-aine määritettiin kuivaamalla 1 t $130 \pm 3{ }^{\circ} \mathrm{C}$ :ssa.

pH määritettiin elektrometrisesti Beckman'in pH-mittarilla American Association of Cereal Chemists'in (1) menetelmää käyttäen.

Fytiinihappofosfori määritettiin MCCANCE ja WidD̊owsonin (10) mukaan, kuitenkin niin muunnettuna, että suodatettua uutetta otettiin $40 \mathrm{ml}: \mathrm{n}$ asemasta vain $20 \mathrm{ml}$, mikä täytettiin $50 \mathrm{ml}: \mathrm{ksi}$. Tästä liuoksesta pipetoitiin $10 \mathrm{ml}$ ja saostettiin $2 \mathrm{ml}: 1 \mathrm{la} \mathrm{FeCl}_{3}$-liuosta (pro $20 \mathrm{ml}$ ja $4 \mathrm{ml}$ ).

Kokonaisfosfori määritettiin Berenblum ja Chainin (2) mukaan. Värin voimakkuus mitattiin Beckman'in spektrofotometrillä aallonpituudella $700 \mu \mathrm{m}$.

1 Osuusliike Elanto r.1.:lle, Helsingin Meijeriliike Oy:lle ja Helsingin Höyryleipomolle saamme tässä yhteydessä lausua parhaat kiitokset ystävällisestä avusta materiaalin hankkimisessa. 
Taulukko 1. Fytiinihapon hajoaminen eri leipälaatuja valmistettaessa.

Table 1. The decomposition of phytic acid in the preparation of different types of bread.

\begin{tabular}{|c|c|c|c|c|c|c|}
\hline \multirow{3}{*}{ Leipälaatu - Type of bread } & \multirow{3}{*}{ 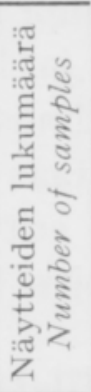 } & \multicolumn{2}{|c|}{ Jauho - Flour } & \multicolumn{2}{|c|}{ Leipä - Bread } & \multirow{3}{*}{ 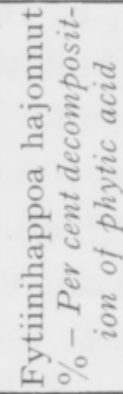 } \\
\hline & & $\begin{array}{l}\text { Kok.-P } \\
\text { Total-P }\end{array}$ & $\begin{array}{c}\text { Fytiini- } \\
\text { happo-P } \\
\text { Phytic } \\
\text { acid-P }\end{array}$ & \multirow{2}{*}{$\mathrm{pH}$} & 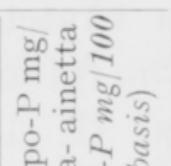 & \\
\hline & & \multicolumn{2}{|c|}{$\begin{array}{c}\mathrm{mg} / 100 \mathrm{~g} \text { kuiva- } \\
\text { ainetta } \\
m g / 100 \mathrm{~g}(d r y \\
\text { basis) }\end{array}$} & & 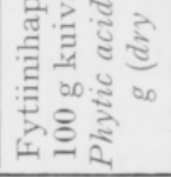 & \\
\hline Ruisleipä, hapan & 21 & $295-400$ & $224--278$ & $4.3-4.7$ & $5-110$ & $45-98$ \\
\hline Soft whole-meal rye bread, sour & & & & & & \\
\hline Ruisleipä, happamaton & 6 & $295-380$ & $210-260$ & $5.0-6.0$ & $41-135$ & $48-81$ \\
\hline Soft whole-meal rye bread, less sour & & & & & & \\
\hline Maalaisruisleipä & 3 & & $262-333$ & $4.3-4.8$ & $14-151$ & $53-95$ \\
\hline Soft whole-meal rye bread, country type & & & & & & \\
\hline Näkkileipä, hapan & 3 & $370-475$ & $275-293$ & $4.3-5.1$ & $40-97$ & $67-85$ \\
\hline Hard, thin whole-meal rye bread, sour & & & & & & \\
\hline Näkkileipä happamaton & 11 & $360-475$ & $224-293$ & $5.4-6.1$ & $94-147$ & $34-59$ \\
\hline Hard, thin whole-meal rye bread, less sour & & & & & & \\
\hline Grahamleipä & 9 & $260-390$ & $202-300$ & $5.8-6.0$ & $91-179$ & $13-55$ \\
\hline Whole-meal wheat bread & & & & & & \\
\hline Ohraleipä & 2 & $255-330$ & $165-220$ & 5.7 & $105-140$ & 36 \\
\hline Whole-meal barley bread & & & & & & \\
\hline Ohra-vehnäleipä & 2 & $205-225$ & $132-147$ & 6.0 & $55-62$ & 58 \\
\hline Barley-wheat bread & & & & & & \\
\hline Ranskanleipä & 3 & $110-133$ & $32-75$ & $5.8-6.0$ & $15-31$ & $38-80$ \\
\hline French loaf & & & & & & \\
\hline
\end{tabular}

\section{Tulokset}

Pehmeä ruis lei pä.

Määritykset suoritettiin kaikkiaan 30 happamasta ja happamattomasta leivästä, joista 21 näytettä oli tehdasvalmisteista, 3 maalaisleipää ja 6 leipää valmistettiin itse. Kaikki leivät oli valmistettu kokojyväjauhoista. Määritysten tulokset käyvät ilmi taulukosta 1. Ne osoittavat, että kaikissa ruisleivissä oli valmistuksen aikana suuri osa fytiinihaposta hajonnut, hajoamisprosentin vaihdellessa $45-98 \%$. Hajoamisen riippuvaisuutta leipien happamuudesta esittää kuva 1. Kutakin näytettä vastaa kuviossa yksi piste, pystyakselin osoittaessa fytiinihappofosforin määrää ja vaakasuoran akselin pH-arvoa. Vaikkakin hajoitus on melkoisen suuri, mikä johtuu käytettyjen jauhojen ja valmistustapojen erilaisuudesta, on selvästi nähtävissä, että alhaisimmat fytiinihappopitoisuudet esiintyvät happamissa leivissä, kun taas eniten fytiinihappoa sisältävät leivät ovat »happamattomia». Tämä onkin ymmärrettävää, koska rukiin fytaasin optimi-pH:n on todettu olevan lähellä $\mathrm{pH}$ $5:$ tä $(7,14,17)$.

Happaman ruisleivän valmistustapoja on meillä monia. Päätyyppeinä voidaan erottaa kaksivaiheinen ja kolme- (tai useampi-) vaiheinen hapantaikinan valmistus- 


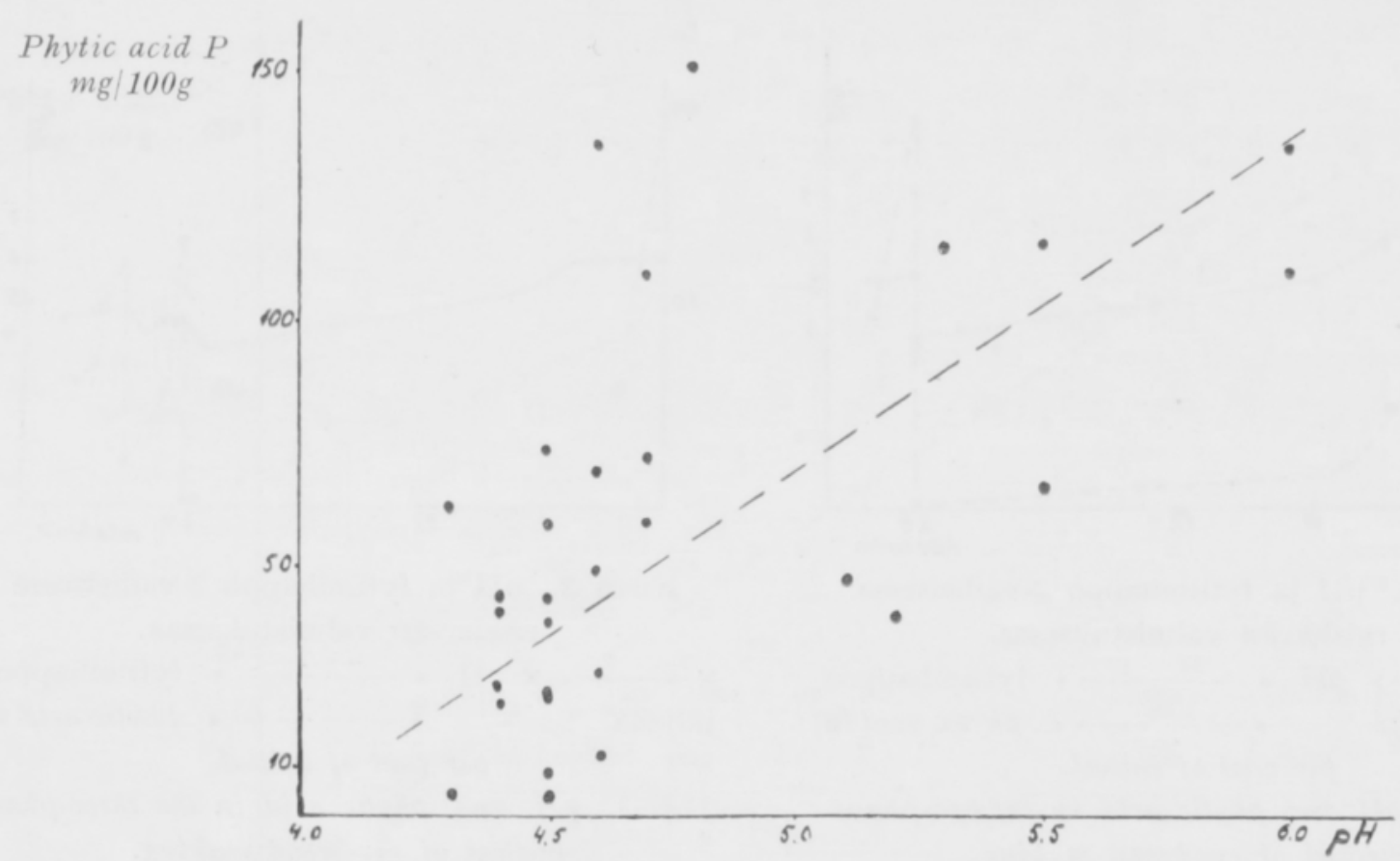

Kuva 1. Ruisleipien $\mathrm{pH}$ ja fytiinihappo.

Fig. 1. pH and phytic acid of the soft whole-meal rye breads.

menetelmä. Kaksivaiheisessa menetelmässä valmistetaan taikinan hapatin ("juuri») koko tarvittavasta vesimäärästä ja pienestä osasta (n. 1/4-1/5) jauhoja ja juuren hapannuttua lisätään loput jauhot kerralla taikinaan. Kolmivaiheinen menetelmä eroaa edellisestä siinä, että jauhot lisätään taikinaseokseen kolmena eränä ja seoksen annetaan aina lisäysten välillä hapantua. Teollisuudessa käytetään hapantaikinan valmistuksessa jälkimmäistä, puolihappaman valmistuksessa edellistä menetelmää (8), kotitaloudessa eri muunnelmina molempia.

Tutkituissa maalaisleivissä oli kolmivaiheisella menetelmällä valmistetussa leivässä yli $90 \%$ fytiinihaposta hajonnut, kun taas kaksivaiheisella menetelmällä valmistetuissa hajoamisprosentti oli vain n. $50 \%$.

Valmistustavan vaikutuksen selvittämiseksi tehtiin koe, jossa taikinat valmistettiin kahdessa ja kolmessa vaiheessa seuraavasti:

Kaksivaiheinen menetelmä:

1. vaihe, hapatin: siementä $+20 \%$ jauhoista $+100 \%$ vedestä.

2. vaihe, taikina: hapatin $+80 \%$ jauhoista.

Kolmivaiheinen menetelmä:

1. vaihe, hapatin: siementä $+15 \%$ jauhoista $+35 \%$ vedestä.

2. vaihe, elvyte: hapatin $+30 \%$ jauhoista $+50 \%$ vedestä.

3. vaihe, taikina: elvyte $+55 \%$ jauhoista $+15 \%$ vedestä.

Seoksen happamuus ja fytiinihappofosfori määritettiin ennen kutakin jauhojen lisäystä ja heti sen jälkeen. Kuva 2 esittää fytiinihappofosforin ja happamuuden muutoksia kaksivaiheisessa ja kuva 3 vastaavia muutoksia kolmivaiheisessa menetelmässä. Kuten kuvista nähdään, ennättää fytiinihappo hajota kolmivaiheisen menetelmän kahdessa esivaiheessa melkein kokonaan, joten taikinassa on sen val- 


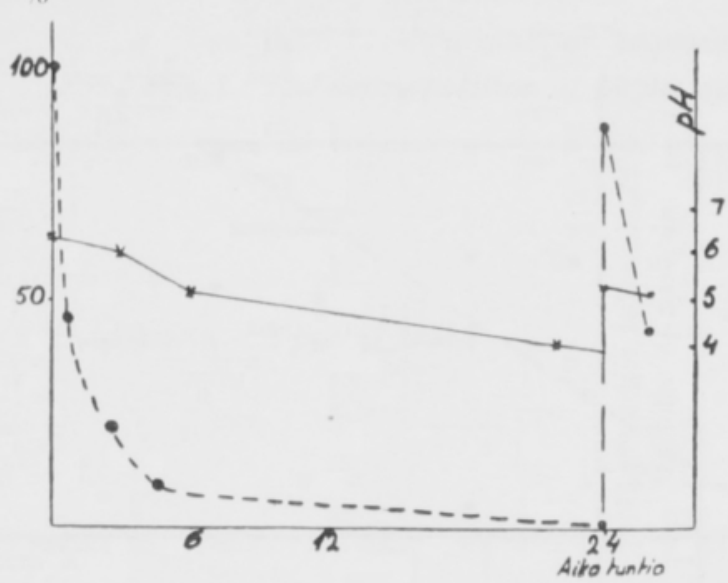

Kuva 2. pH ja fytiinihappo 2-vaiheisessa ruisleivän valmistuksessa.

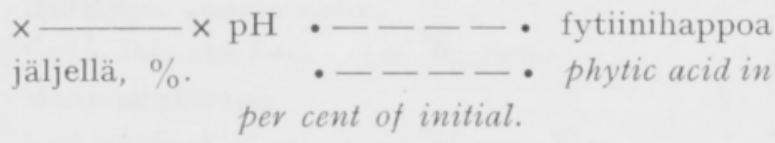

Fig. 2. $p H$ and phytic acid in the two-phase method of rye-bread making.

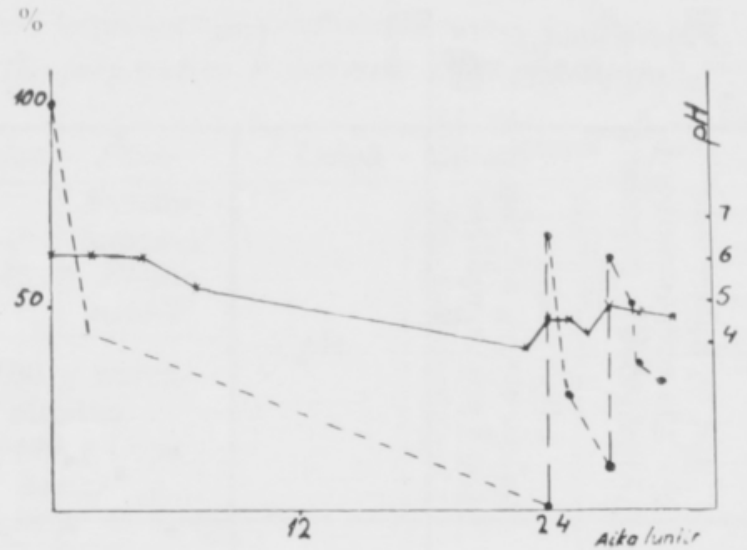

Kuva 3. pH ja fytiinihappo 3-vaiheisessa ruisleivän valmistuksessa.

$\times — \times \mathrm{pH} \cdot-\_-\ldots$ fytiinihappoa jäljellä, \%. $\quad \cdot-\_-\ldots$ phytic acid in per cent of initial.

Fig. 3. pH and phytic acid in the three-phase method of rye-bread making.

mistuessa jäljellä vain viimeisessä vaiheessa lisättyjen jauhojen fytiinihappo, eli n. 55-60\% käytetyn jauhomäärän alkuaan sisältämästä määrästä. Kaksivaiheisessa menetelmässä, jossa lopullista taikinaa valmistettaessa hapattimeen lisätään yhdellä kertaa $80 \%$ jauhoista, on taikinan valmistuessa sitävastoin fytiinihaposta vielä hajoamatta noin $80 \%$. Koska taikinan happamuus tässä vaiheessa on molemmissa tapauksissa fytaasin toiminnalle edullinen, tasoittaa pitkä nousutus- ja paistoaika (leipien ollessa suurikokoisia) kuitenkin eroavuutta eri menetelmien valmistettujen leipien fytiinihappopitoisuuksissa. Tämä käykin kokeesta ilmi, sillä valmiiden leipien fytiinihappopitoisuuksien ero on huomattavasti pienempi kuin vastaavien taikinoiden välinen ero.

$\mathrm{N}$ äk kilei pä.

Näkkileivissä, joita tutkittiin yhteensä 14 näytettä, on happamuuden vaikutus leivän fytiinihappopitoisuuteen todettavissa vielä selvemmin kuin pehmeissä ruisleivissä (taulukko 1 ja kuva 4). Happamissa näkkileivissä ( $\mathrm{pH} 4.3-5.1$ ) on jauhojen fytiinihaposta hajonnut $67-85 \%$, kun taas happamattomissa ( $\mathrm{pH} 5.5-6.1$ ) vastaavat luvut ovat $34-59 \%$. Fytiinihapon hajoamis- $\%$ näkkileipää valmistettaessa on ollut keskimäärin $10-20 \%$ pienempi kuin happamuudeltaan vastaavan pehmeän ruisleivän valmistuksessa, mikä ilmeisesti johtuu fytaasin nopeammasta termisestä inaktivoitumisesta ohuita näkkileipiä paistettaessa.

Hi ivaleipä.

Useimmat tutkituista hiivaleivistä olivat kaupallisia grahamleipiä $(9 \mathrm{kpl})$, jotka eivät ole pelkästään kokojyväjauhoista valmistettuja, vaan sisältävät osittain myös valkoisia vehnäjauhoja. Seitsemässä näytteessä, jotka kaikki olivat saman leipomon valmistamia, oli fytiinihappofosforin määrä varsin korkea, useimmissa 


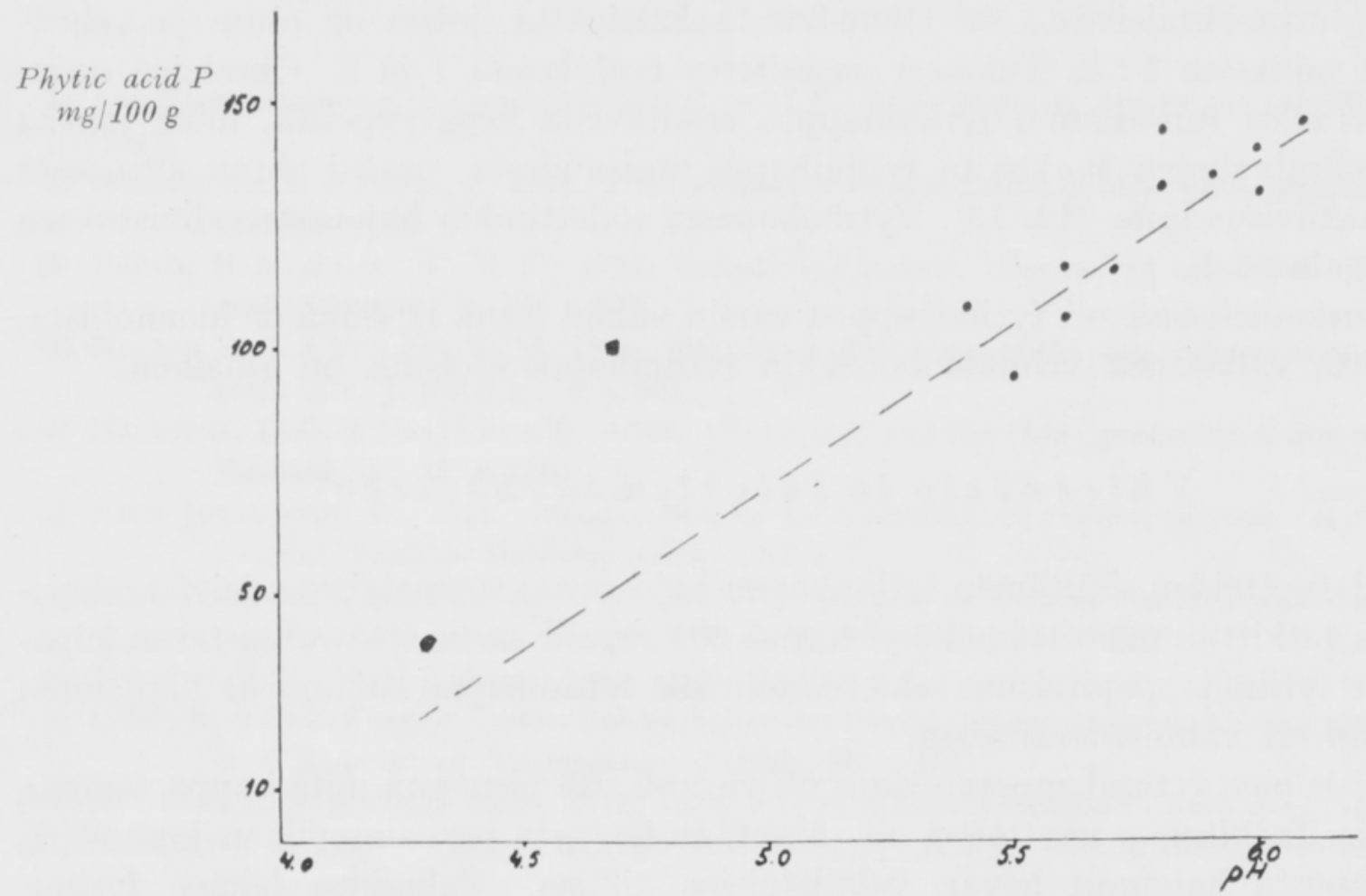

Kuva 4. Näkkileipien $\mathrm{pH}$ ja fytiinihappo.

Fig. 4. pH and phytic acid of the hard thin whole-meal rye-breads.

tapauksissa yli $170 \mathrm{mg} / 100 \mathrm{~g}$ (taul. 2), joten fytiinihapon hajoamisprosentti oli jäänyt hyvin alhaiseksi (keskimäärin $25 \%$ :ksi). Kahdessa tapauksessa fytiinihappofosforin määrä oli huomattavasti edellä mainittua alhaisempi, suuruusluokkaa $100 \mathrm{mg} / 100 \mathrm{~g}$ fytiinihapon hajoamisprosentin ollessa tällöin $55 \%$. Viimeksi mainitut vähän fytiinihappoa sisältävät grahamleivät olivat eri leipomon valmistamia kuin edelliset, joten ero johtunee valmistustavan erilaisuudesta.

Aikaisemmin Suomessa runsaastikin käytetyn ohraleivän ja ohravehnäleivän fytiinihappopitoisuuden selvittämiseksi tehtiin määritykset kahdesta laboratoriossa

Taulukko 2. Fytiinihappofosforin määrä hiivaleivissä.

Table 2. The phytic acid content of nyeast-breads»

\begin{tabular}{|c|c|c|}
\hline \multirow{2}{*}{$\begin{array}{c}\text { Leipälaatu } \\
\text { Type of bread }\end{array}$} & \multicolumn{2}{|c|}{$\begin{array}{l}\text { Fytiinihappofosforia, mg/100 g kuiva-ainetta } \\
\text { Phytic acid phosphorus, mg/100 g (dry basis) }\end{array}$} \\
\hline & $\begin{array}{l}\text { eri näytteissä } \\
\text { in different samples }\end{array}$ & $\begin{array}{l}\text { keskim. } \\
\text { average }\end{array}$ \\
\hline Grahamleipä & $179,176,176,175,175$ & 155 \\
\hline Whole-meal wheat bread & $174,142,105,91$ & \\
\hline Ohraleipä & 140,105 & 123 \\
\hline Whole-meal barley bread & & \\
\hline Ohra-vehnäleipä & 62,55 & 58 \\
\hline Barley-wheat bread & & \\
\hline Ranskanleipä & $31,15,20$ & 22 \\
\hline Fvench loat" & & \\
\hline
\end{tabular}


valmistetusta ohraleivästä sekä kahdesta sekaleivästä, joissa oli ohra- ja vehnäjauhoja suhteessa $1: 1$. Tulokset on esitetty taulukoissa 1 ja 2 . Ohraleipä osoittautui erääksi runsaimmin fytiinihappoa sisältävistä leipätyypeistä, mikä johtuu osaksi ohrajauhojen korkeasta fytiinihappopitoisuudesta, osaksi ohran alhaisesta fytaasiaktiivisuudesta $(12,13)$. Fytiinihaposta todettiinkin hajoneen valmistuksen aikana vain $36 \%$.

Ranskanleivässä oli fytiinihappoa varsin vähän (taul. 1), mikä on luonnollista, koska itse valkoisissa vehnäjauhoissakin fytiinihappopitoisuus on alhainen.

\section{Yhteenveto ja tulosten tarkastelu}

Viljatuotteiden sisältämän fytiinihapon hajoamista suomalaisessa leivänvalmistuksessa tutkittiin määrittämällä yhteensä 60 kaupallisen tai itse valmistetun leipänäytteen fytiinihappopitoisuus sekä seuraamalla fytiinihapon hajoamista happamen ruisleivän eri valmistusvaiheissa.

Ruisleipien fytiinihappopitoisuus oli yleensä sitä pienempi mitä happamempaa leipä oli. Tutkituissa näytteissä oli vähintään $50 \%$ ja parhaimmillaan jopa $98 \%$ fytiinihaposta hajonnut leivän valmistuksen aikana. Valmiiden leipien fytiinihappofosforin määrä vaihteli välillä $5-151 \mathrm{mg} / 100 \mathrm{~g}$. Kolmivaiheisessa valmistusmenetelmässä hajoaminen tapahtui tehokkaammin kuin kaksivaiheisessa menetelmässä. Näkkileivissä fytiinihapon hajoamisprosentti oli $10-20 \%$ pienempi kuin happamuudeltaan vastaavissa pehmeissä leivissä.

Runsaimmin fytiinihappoa sisältäviksi leipätyypeiksi todettiin graham- ja ohrajauhoista valmistetut hiivaleivät. Niiden valmistuksen aikana jauhojen fytiinihaposta hajoaa keskimäärin vain 25-35\%. Valmiiden leipien keskimääräinen fytiinihappofosforipitoisuus oli $120-170 \mathrm{mg} / 100 \mathrm{~g}$.

Viljatuotteiden kulutus Suomessa nykyään on arvioitu keskimäärin 315 g:ksi henkeä ja päivää kohti, josta määrästä noin $100 \mathrm{~g}$ on ruista, $50 \mathrm{~g}$ kokojyvävehnää, $125 \mathrm{~g}$ valkoista vehnäjauhoa ja loput kauraa ja ohraa (15). Jos oletetaan, että ruis ja vehnä nautitaan leipänä ja muu vilja puuroksi valmistettuna, sisältää suomalainen ruoka edellä esitetyistä tuloksista saatujen keskimääräisten fytiinihappofosforipitoisuuksien mukaan laskettuna päivittäin leivässä n. $155 \mathrm{mg}$ ja puurossa n. $75 \mathrm{mg}$ eli yhteensä n. $230 \mathrm{mg}$ fytiinihappofosforia. Olettaen, että fytiinihappo poistuu suolistosta pentakalsiumfytaattina (6), saostaa tämä fytiinihappomäärä n. $240 \mathrm{mg}$ kalsiumia. Mainitut viljatuotteet itse sisältävät $90 \mathrm{mg}$ kalsiumia (19), joten nautittujen viljatuotteiden voidaan laskea riistävän muun ruoan sisältämästä kalsiumista $150 \mathrm{mg}$ eli määrän, joka sisältyy esim. 125 ml:aan maitoa. Ottaen huomioon, että suomalainen ruokavalio sisältää keskimäärin yli $1300 \mathrm{mg}$ (15) kalsiumia henkeä ja päivää kohti, voidaan fytiinihapon sitomaa kalsiumin määrää pitää varsin pienenä. Näin ollen näyttää viljatuotteiden ruokamme kalsiumtaloutta huonontava vaikutus suhteellisen vähäiseltä. 


\section{KIRJALLISUUTTA}

(1) American Association of Cereal Chemists Cereal Laboratory Methods, 5th Ed., s. 158. Minneapolis 1947.

(2) Berenblum, I. \& Chain, E. 1938. The colorimetric determination of phosphate. Biochem. J., 32, S. 295.

(3) Bruce, H. M. \& Callow, R. K. 1934. Cereals and rickets. The role of inositolhexaphosphoric acid. Biochem. J., 28, s. 517.

(4) Harris, R. S. \& Bunker, W. M. 1935. The phytin phosphorus of the corn component of a rachitogenic diet. J. Nutrition 9, s. 301.

(5) Harrison, D. C. \& Mellanby, E. 1939. Phytic acid and the ricketsproducing action of cereals. Biochem. J., 33, s. 1660.

(6) Hoff-Jørgensen, E. 1944. Investigation on the solubility of calcium phytate. Kgl. Danske Vidensk. Selskab. Mat.-fys. Medd. XXI, s. 7.

(7) Hoff-Jørgensen, E. \& Porsdal, V. 1947. On phytase activity in rye flour and the phytate content of rye bread. Trans. Dan. Acad. Techn. Sci., Nr. 2.

(8) Itkonen, J. V. 1951. Leipurin kirja, s. 92. Helsinki.

(9) Lang, K. \& Eberwein, A. 1948. Das Verhalten des Phytins bei der Sauerteigführung von Roggenbrot. Z. Lebensm. Untersuch. u. Forsch., 88, s. 153.

(10) McCance, R. A. \& Widdowson, E. M. 1935. Phytin in human nutrition. Biochem. J., 26, s. 2694.

(11) Mellanby, E. 1920 - Lancet, 1. 1290. Ref. Mellanby, A story of nutritional research, s. 208, Baltimore 1950 .

(12) Mellanby, E. 1950. A story of nutrional research, s. 260. Baltimore.

(13) Møllgatird, H. \& Lorenzen, K., Hausen, I. G. \& Christensen, P. E. 1946. On phytic acid, its importance in metabolism and its enzymic cleavage in bread supplemented with calcium. Biochem. J., 40, s. 589.

(14) Pedersen, J. G. A. 1940. Experimental rakitis hos svin. Bereting fra Landøkonomisk Forsøkslaboratorium, n:o 193, København. Ref. Mellanby, A sotry of nutritional research, s. 257.

(15) Ravintotasekomitean suorittama arvio, 1952.

(16) Schulerud, A. 1944. The contents of phytic acid P in Norwegian flour and bread types I. Acta Physiol. Scand., 8, s. 259.

(17) $\longrightarrow$ - 1947. The contents of phytic acid P in Norwegian flour and bread types II. Acta Physiol. Scand., 14, s. 1.

(18) Starkenstein, E. 1910. Die biologische Bedeutung der Inositphosphorsäure. Biochem. Z., 30, S. 56 .

(19) Turpeinen, O. \& Roine, P. 1952. Ruoka-ainetaulukko, s. 10. Helsinki.

(20) Widdowson, E. M. 1941. Phytic acid and preparation of food. Nature, 148, s. 219.

\section{SUMMARY:}

\section{ON THE PHYTIC ACID CONTENT OF FINNISH BREADS}

Rakel Kurkela, Eeva Korhonen, Marjatta Rossander and Paavo Roine

\section{Department of Nutritional Chemistry, University of Helsinki, Finland}

60 commercial bread samples representing the types of bread most commonly used in Finland were analyzed for their phytic acid content. Several bread samples were made in the laboratory and in some cases the decomposition of phytic acid was followed during the different phases of bread making process. 
The phytic acid content of rye bread was found to decrease with increasing acidity. In the samples investigated at least 50 per cent, in the best cases even 98 per cent, of the phytic acid originally found in the flour had been decomposed during the baking, the finished bread containing 5 to $151 \mathrm{mg}$ of phytic acid phosphorus in 100 grams dry matter. The decomposition was more complete in the breads made by a three-phase baking procedure than in those baked in two phases.

In thin hard rye breads the decomposition of phytic acid was 10-20\% lower than the corresponding percentage in the soft breads of the same acidity.

The highest phytic acid content, $120-170 \mathrm{mg}$ phytic acid phosphorus per 100 grams, was found in the so-called yeast-breads made from wholemeal wheat or barley. The decomposition in these cases were as low as $25-35 \%$.

The total per capita consumption of cereal products in Finland has been estimated to average 315 grams per day. Of this amount about 100 grams is rye, 50 grams whole-meal wheat, 125 grams white wheat flour, and the rest oats and barley. Assuming that rye and wheat are consumed as bread and other cereals as porridge, it can be calculated on the basis of the above results that the total phytate phosphorus content of bread amounts to about $155 \mathrm{mg}$ and that of porridge to $75 \mathrm{mg}$ per person per day. These amounts of phytic acid are able to bind a total of $240 \mathrm{mg}$ calcium as pentacalciumphytate. Taking the cereals' own calcium content (about $90 \mathrm{mg}$ ) into consideration it can be calculated that the cereals consumed may render about $150 \mathrm{mg}$ calcium of other foodstuffs unavailable. Since the average Finnish diet consists of at least $1300 \mathrm{mg}$ of calcium per day the total loss due the phytic acid of cereals cannot be considered to constitute a serious nutritional problem.

\title{
MAATALOUSTIETEELLINEN AIKAKAUSKIRJA
}

\author{
Ilmari Poijärvi \\ Päätoimittaja
}

Tikkurila. Puh. 831244 ja 831308

TOIMITUSKUNTA

\author{
E. Kitunen, J. O. Sauli, Erkki Kivinen, Aarne Virtamo \\ MAATALOUSTIETEELLISTÄ AIKAKAUSKIRJAA \\ ilmestyy 4 vihkoa vuodessa sisältäen kukin $2-4$ painoarkkia
}

Käsikirjoitukset lähetetään joko päätoimittajalle tai toimitussihteerille (os. Tikku= rila) tai jollekin toimitusvaliokunnan jäsenelle

\section{SUOMEN MAATALOUSTIETEELLINEN SEURA}

Puheenjohtaja:

Professori Onni Pohjakallio,

Viikin koetila, Malmi

Varapuheenjohtaja :

Professori Antti Mäki,

Mannerheimintie $35 \mathrm{~B}$, Helsinki

\section{Sihteeri :}

Professori V. Vainikainen, Kasarmik. 38 A 8, Helsinki

$$
\text { Rahastonhoitaja: }
$$

Maisteri Aarne Virtamo. Maataloushallitus, Helsinki 